\title{
ANALISIS SISTEM PENGELOLAAN SAMPAH MEDIS PUSKESMAS PERAWATAN DI KABUPATEN MERANGIN
}

\author{
Analysis Of Medical Waste Management System Health Center Maintenance In District Of \\ Merangin
}

Romaningsih ${ }^{1}$, Asparian $^{2}$

${ }^{1}$ Prodi S1 Kesehatan Masyarakat, STIKes Merangin

${ }^{2}$ Prodi Kesehatan Masyarakat, FKM Universitas Jambi

\begin{abstract}
Abstrak
Kabupaten Merangin memiliki 6 puskesmas Perawatan yang mempunyai alat incinerator namun dalam keadaan rusak dan 4 puskesmas lain tidak mempunyai alat incinerator. Tujuan penelitian ini adalah untuk mengetahui sistem pengelolaan sampah medis Puskesmas Perawatan Di Kabupaten Merangin Tahun 2016 mulai dari pemilahan, pengumpulan, pengangkutan, penampungan sementara dan pembuangan akhir sampah medis. Jenis penelitian ini menggunakan pendekatan kualitatif dengan rancangan studi kasus deskriptif. Penelitian ini dilakukan di 10 Puskesmas Perawatan Kabupaten Merangin Tahun 2016. Informan dalam penelitian ini berjumlah 61 Orang terdiri dari Kasi penyehatan Lingkungan Dinkes Merangin, Kepala Puskesmas, Petugas Kesehatan Lingkungan, Petugas Laboratorium, Kepala Ruang Perawatan, Perawat, dan Cleaning Service. Instrumen yang digunakan dalam penelitian ini adalah human instrument, pedoman wawancara, daftar checklist, alat perekam gambar, suara dan alat tulis. Teknik analisis data kualitatif menggunakan reduksi data, penyajian data dan penarikan kesimpulan. Pengelolaan sampah medis di 10 Puskesmas Perawatan Kabupaten Merangin, memiliki proses yang sama yaitu melakukan pemilahan sampah medis dan sampah non medis, pengumpulan dan pengangkutan sampah ke tempat pembakaran. Kemudian dilakukan proses akhir pengelolaan sampah medis padat dengan pembakaran manual. Tetapi tidak melakukan pembakaran dengan alatincinerator dan tidak melakukan kerja sama dengan rumah sakit yang mempunyai alat incineratoruntuk pemusnahan sampah medis. Kesimpulan penelitian ini adalah, sistem pengelolaan sampah medis Puskesmas Perawatan di Kabupaten Merangin Tahun 2016 belum sesuai dengan KepmenkesNo 1428/MENKES/SK/XII/2006.
\end{abstract}

Kata Kunci : : Sampah Medis, Proses Pengelolaan Sampah Medis

\begin{abstract}
The Merangin regency, there are 6 primary health centers which also have incinerator, but not in good condition. 4 other health centers do not have incinerator. The purpose of this research was to know the medical waste management system at medical care health centers in Merangin regency 2016. the researched was started with sorting, collcting, transferring, temporary storage and final disposal of medical waste. This research was qualitative approach with descriptive case study design. This study was conducted in 10 care health centers of Merangin regency. The Informants in this study were 61 people, which is consist of the chief of environmental health department of Merangin, head of the care health center, environmental health officers, laboratory staff, the head of the nurse, nurses and cleaning service. The instrument of the study was human instrument, interview, check list, image recording devices and stationery. The Qualitative data analysis techniques was calculate by using data reduction technique, data presentation and conclusion. The process of medical waste management in 10 care health centers in merangin regency basically have the same process, namely through the process of selecting between medical and non medical waste, collecting the wastes and transfering the waste into the incinerator. The final process of solid medical waste was the burning process which was done manually, the incinetor was not included to be burned and the clinic did not make cooperation with the hospital in case to burn the medical waste. Conclusion is the Medical waste management system at medical care health centers in the Merangin regency was still not managed well as accordance with Kepmenkes No 1428/MENKES/ SK/XII/2016.
\end{abstract}

Keyword : : Medicalwaste, Management process.

Korespondensi: Asparian

Email: aspariantujuhsatu@gmail.com 


\section{PENDAHULUAN}

Puskesmas perawatan dalam kegiatan pelayanan kesehatan menghasilkan sampah medis dan sampah non medis baik dalam bentuk padat maupun cair. Sampah medis adalah suatu material yang sangat berbahaya serta limbah yang langsung dihasilkan dari tindakan diagnosis dan tindakan medis terhadap pasien. Sampah medis dalam bentuk padat di puskesmas perawatan biasanya dihasilkan dari kegiatan yang berasal dari ruang rawat inap, poliklinik umum, poliklinik gigi, poliklinik ibu dan anak atau KIA (kesehatan ibu dan anak), laboratorium dan apotik. Contoh sampah medis dalam bentuk padat yaitu spuit (jarum suntik), botol vaksin, kapas, pot dahak dan bandage (perban). Sementara sampah medis dalam bentuk cair atau lebih sering disebut limbah cair biasanya berasal dari laboratorium puskesmas yang kemungkinan mengandung mikroorganisme, bahan kimia beracun, dan radioaktif. Contoh limbah medis dalam bentuk cair yaitu darah, dahak dan reagen dari laboratorium ${ }^{1}$.

Sampah non medis adalah semua sampah padat diluar sampah padat medis yang dihasilkan dari berbagai kegiatan seperti kantor, administrasi, unit perlengkapan, ruang tunggu, ruang inap, unit gizi atau dapur, halaman parkir, taman dan unit pelayanan. Contoh sampah non medis yaitu plastik, kertas, daun, bekas makanan dan lain-lain ${ }^{1}$.

Sampah medis yang dihasilkan puskesmas, apabila tidak didukung dengan perencanaan dan pengelolaan yang matang akan berpotensi menimbulkan dampak terhadap masyarakat dan lingkungan. Sampah medis maupun non medis harus dilakukan pengelolaan yang baik. Pengelolaan sampah adalah kegiatan yang sistematis, menyeluruh, dan berkesinambungan yang meliputi pengurangandan penanganan $\operatorname{sampah}^{10}$. Proses pengelolaan sampah medis berdasarkan Kepmenkes RI No.1428/Menkes/SK/XII/2006 yaitu mulai dari pemilahan, pengumpulan, pengangkutan, penampungan sementara dan penangganan akhir sampah. Pengolahan sampah medis yang memenuhi standar mengggunakanincinerator dengan suhu diatas $800{ }^{\circ} \mathrm{C}$ sampai $1000{ }^{\circ} \mathrm{C}$ dan pembuangan akhirnya di gali terus ditutup kembali (Sanittarylandfill).

Menurut pusat data dan informasi (Pusdatin) Kementrian Kesehatan Republik Indonesia tahun 2015, jumlah puskesmas di Indonesia sampai dengan

bulan juni 2015 tercatat sebanyak 9.740 unit puskesmas. Jumlah tersebut terdiri dari 3.395 unit puskesmas rawat inap dan 6.345 unit puskesmas non rawat inap. Persentase puskesmas yang melakukan pemisahan sampah medis dan non medis sebesar $64,6 \%$ puskesmas, serta hanya $26,8 \%$ puskesmas yang memiliki alat incinerator.Di provinsi Jambi puskesmasnya tercatat sebanyak 180 unit puskesmas yang terdiri dari 69 unit puskesmas rawat inap dan 111 unit puskesmas non rawat inap9.

Di Kabupaten Merangin berdasarkan profil Kesehatan Kabupaten Merangin tahun 2015 tercatat 23 unit puskesmas yang terdiri dari 10 unit puskesmas perawatan dan 13 unit puskesmas non perawatan ${ }^{2}$. Dalam penanganan sampah medis puskesmas di Kabupaten Merangin belum ada satu pun puskesmas yang menggunakan incinerator untuk pengolahan sampah medis padat. Namun ada 2 puskesmas yaitu Puskesmas Pematang Kandis dan Puskesmas Bangko yang dalam penanganan sampah medisnya melakukan kerja sama dengan RSUD Kolonel Abundjani Bangko dengan MOU (Memorandum OfUnderstanding) Nomor 443/1610.1/Dinkes/2015 dan Nomor 445/496/RSUD/2015 tanggal 17 september 2014.

Puskesmas perawatan yang ada di Kabupaten Merangin berjumlah 10 unit puskesmas yaitu Puskesmas Muara Siau, Puskesmas Pasar Masurai, Puskesmas Meranti, Puskesmas Sungai Manau, Puskesmas Rantau Panjang, Puskesmas Muara Delang, Puskesmas Sungai Bulian, Puskesmas Pamenang, Puskesmas Muara Jernih, dan Puskesmas Muara Madras. Dari ke 10 puskesmas perawatan tersebut penanganan sampah medis padatnya tidak dipisah dengan sampah non medis, dan tidak ada yang menggunakan incinerator serta hanya 1 (satu) puskesmas yang menggunakan pelebur jarum yaitu Puskesmas Sungai Bulian dalam penanganan sampah medis padatnya. Pemusnahaannya dibakar dan pembuangan akhirnya digalian yang bercampur dengan sampah medis dan non medis. Kemudian setelah penuh baru dikubur. Serta tidak adanya Standar Operasional Prosedure (SOP) tentang pengelolaan sampah medis di puskesmas perawatan. Biarpun ada Standar Operasional Prosedure (SOP) tapi tidak digunakan sebagai aturan atau langkahlangkah untuk mengelola sampah medis. Dalam observasi ke 10 puskesmas di temukan 6 unit 
incineratoryaitu di Puskesmas Meranti, Puskesmas Sungai Manau, Puskesmas Rantau Panjang, Puskesmas Muara Delang, Puskesmas Pamenang, dan Puskesmas Muara Jernih. Selanjutnya setelah di amati ternyata incineratortersebut dalam keadaan tidak dirawat, tidak digunakan lagi, rusak, berkarat, berdebu, ada yang hilang di salah satu bagiannya, bergambar dan di kiri kanannya banyak ditumbuhi bunga serta pohon.

Berdasarkan alasan-alasan tersebutlah peneliti menetapkan 10 Puskesmas Perawatan di Kabupaten Merangin sebagai lokasi penelitian untuk membandingkan, menganalisis dan mengkaji mengenai proses pengelolaan sampah medis Puskesmas Perawatan di Kabupaten Merangin tahun 2016 dengan Kepmenkes RI No.1428/Menkes/SK/XII/2006

\section{METODE PENELITIAN}

Jenis penelitian ini menggunakan pendekatan kualitatif dengan rancangan studi kasus deskriptif. Penelitian ini dilakukan di 10 Puskesmas Perawatan Kabupaten Merangin Tahun 2016 yaitu Puskesmas Muara Siau, Puskesmas Pasar Masurai, Puskesmas Meranti, Puskesmas Sungai Manau, Puskesmas Rantau Panjang, Puskesmas Muara Delang, Puskesmas Sungai Bulian, Puskesmas Pamenang, Puskesmas Muara Jernih, dan Puskesmas Muara Madras.

Hasil wawancara di puskesmas perawatan Kabupaten Merangin terhadap para petugas medis dan non medis didapatkan hasil bahwa $30 \%$ kepala puskesmas, $20 \%$ petugas kesling, $20 \%$ petugas laboratorium, $40 \%$ kepala ruang perawatan dan $60 \%$ perawat mengetahui pengertian sampah medis sesuai Kepmenkes Republik Indonesia No.1428/Menkes /SK/XII/2006. Namun 70\% kepala puskesmas, $80 \%$ petugas kesling, $80 \%$ petugas laboratorium, $60 \%$ kepala ruang perawatan, $40 \%$ perawat dan $100 \%$ petugas cleaningservice tidak mengetahui yang dimaksud sampah medis yang sesuai dengan Kepmenkes RI No.1428/Menkes/ SK/ XII/2006. Namun mengetahui contoh sampah medis yang sering dihasilkan.
Informan dalam penelitian ini berjumlah 61 Orang terdiri dari Kasi penyehatan Lingkungan Dinkes Merangin, Kepala Puskesmas, Petugas Kesehatan Lingkungan, Petugas Laboratorium, Kepala Ruang Perawatan, Perawat, dan Cleaning Service. Instrumen yang digunakan dalam penelitian ini adalah human instrument, pedoman wawancara, daftar checklist, alat perekam gambar, suara dan alat tulis. Teknik analisis data kualitatif menggunakan reduksi data, penyajian data dan penarikan kesimpulan.

\section{HASIL PENELITIAN DAN PEMBAHASAN}

1. Pengetahuan Petugas Tentang Pengelolaan Sampah Medis

Pengetahuan adalah hasil pengindraan manusia, atau hasil tahu seseorang terhadap objek melalui indra yang dimilikinya yaitu mata, hidung, telingga dan sebagainya ${ }^{6}$. Sedangkan menurut Kepmenkes RI No.1428/Menkes/SK/XII/2006, yang dimaksud dengan sampah medis puskesmas adalah semua sampah yang dihasilkan dari kegiatan medis puskesmas bisa dalam bentuk padat maupun cair. Petugas memperoleh pengetahuan terkait dengan pengelolaan sampah medis dari kenyataan (fakta) yang ada di lapangan dengan menilai dan mendengar sendiri serta melalui media komunikasi seperti mediacetak dan kegiatan penyuluhan serta pelatihan.

Semua puskesmas perawatan di Kabupaten Merangin mempunyai pengetahuan cukup memadai tentang sampah medis padat. Sebagian besar petugas medis dan non medis menjawab bahwa yang di maksud sampah medis adalah sampah hasil dari tindakan pelayanan medis puskesmas. Sedangkan contoh sampah medis yang sering disebutkan yaitu ampul, spuit, nail, kasa, verban, botol bekas infus, botol bekas obat dan lain-lain. Secara keseluruhan jawaban yang diberikan informan menunjukkan tingkat pengetahuan petugas medis maupun non medis cukup memadai.

Hasil penelitian ini tidak sejalan dengan penelitian Dyah (2013) dikarenakan hasil keselurhan jawaban dari narasumber sudah 
menunjukkan bahwa tingkat pengetahuan petugas medis pada Puskesmas di Kabupaten Pati sudah cukup baik ${ }^{3}$.

\section{Pelatihan Pengelolaan Sampah Medis}

Pelatihan merupakan salah satu upaya untuk meningkatkan pengetahuan, sikap dan keterampilan petugas dalam rangka meningkatkan mutu dan kinerja petugas. Tujuan pelatihan adalah agar petugas yang bertanggung jawab mempunyai pengetahuan dan kemampuan yang cukup dalam pengelolaan sampah medis, sehingga terwujud sarana layanan kesehatan yang berwawasan lingkungan yang aman dan nyaman bagi petugas maupun masayarakat.

Pelatihan sangat diperlukan bagi petugas kesling dan petugas cleaning service puskesmas yaitu sebagai langkah awal dari pelaksanaan pengelolaan sampah medis sehingga petugas memiliki acuan dan pedoman dalam melaksanakan tugasnya.

Tabel 1. Pelatihan Pengelolaan Sampah Medis di Puskesmas Perawatan Kabupaten Merangin Tahun 2016

\begin{tabular}{|c|c|c|c|c|c|c|c|c|}
\hline \multirow{3}{*}{ No } & \multirow{3}{*}{ Puskesmas } & \multicolumn{6}{|c|}{ Informan } & \multirow{3}{*}{ Presentase } \\
\hline & & \multicolumn{2}{|c|}{ Kepala Puskesmas } & \multicolumn{2}{|c|}{ Petugas Kesling } & \multicolumn{2}{|c|}{ Cleaning Service } & \\
\hline & & Ada & Tidak & Ada & Tidak & Ada & Tidak & \\
\hline 1. & Meranti & - & $\checkmark$ & $\checkmark$ & - & - & $\checkmark$ & $10 \%$ \\
\hline & Muara Delang & - & $\checkmark$ & - & $\checkmark$ & - & $\checkmark$ & \multirow{9}{*}{$90 \%$} \\
\hline & Muara Jernih & - & $\checkmark$ & - & $\checkmark$ & - & $\checkmark$ & \\
\hline 4. & Muara Madras & - & $\checkmark$ & - & $\checkmark$ & - & $\checkmark$ & \\
\hline & Muara Siau & - & $\checkmark$ & - & $\checkmark$ & - & $\checkmark$ & \\
\hline & Pasar Masurai & - & $\checkmark$ & - & $\checkmark$ & - & $\checkmark$ & \\
\hline & Pamenang & - & $\checkmark$ & - & $\checkmark$ & - & $\checkmark$ & \\
\hline & Rantau Panjang & - & $\checkmark$ & - & $\checkmark$ & - & $\checkmark$ & \\
\hline & Sungai Bulian & - & $\checkmark$ & - & $\checkmark$ & - & $\checkmark$ & \\
\hline 10. & Sungai Manau & - & $\checkmark$ & - & $\checkmark$ & - & $\checkmark$ & \\
\hline
\end{tabular}

Hasil wawancara dan telaah dokumen di semua Puskesmas Perawatan hanya terdapat satu petugas kesling $(10 \%)$ yang telah melakukan pelatihan pengelolaan sampah medis, $90 \%$ belum pernah mengikuti pelatihan serta semua petugas cleaning service $(100 \%)$ belum pernah mengikuti pelatihan pengelolaan sampah medis. Pelatihan petugas kesling tentang orientasi peningkatan kapasitas sanitarian juga termasuk pengelolaan sampah medis yang sesuai dengan Kepmenkes RI No.1428/Menkes/SK/XII/2006 yang dilaksanakan oleh Dinas Kesehatan Provinsi Jambi pada bulan Mei tahun 2016. Namun hasil pelatihan tersebut belum dijalankan, disebabkan oleh alat pemusnah sampah medis (incinerator) sudah tidak bisa digunakan lagi.

\section{Standart Operasional Prosedure (SOP) Pengelolaan Sampah Medis}

SOP merupakan tatacara atau tahapan yang dibakukan dan harus dilalui untuk menyelesaikan suatu proses kerja tertentu. Atau suatu panduan yang menjelaskan secara terperinci bagaimana suatu proses harus dilaksanakan ${ }^{4}$. SOP dibuat mempunyai tujuan, fungsi dan manfaat yaitu bisa menjelaskan secara detail setiap kegiatan yang dijalankan, standarisasi kegiatan, dan memudahkan mengarahkan suatu pekerjaan kepada konsep yang jelas.

Standart operasional prosedure (SOP) dalam pengelolaan sampah medis berisi tentang pengertian, jenis dan contoh sampah medis, serta tujuan dari pembuatan SOP, kebijakan kepala puskesmas, referensi peraturan mengenai pengelolaan sampah medis, prosedur yang harus 
sesuai dengan Kepmenkes RI No.1428/ dimana letak kesalahannya serta dapat Menkes/SK/ XII/2006, dan unit terkait.

Dalam setiap kegiatan pekerjaan yang dilakukan oleh setiap petugas harus mempunyai SOP, pedoman, acuan dan pegangan yang jelas, sehingga dengan adanya alur pedoman yang jelas maka pekerjaan dapat berjalan dengan lancar. Jika terjadi kesalahan atau kekeliruan dalam suatu pengelolaan dapat di analisis meminimalisir kecelakaan. SOP pengelolaan sampah medis yang tepat dan sesuai dengan peraturan perundang-undangan yang berlaku, maka akan menjamin keselamatan dan kesehatan karyawan maupun orang yang berada di lingkungan puskesmas.

Tabel 2. Persentase Informan Tentang SOP Pengelolaan Sampah MedisDi Puskesmas Perawatan Kabupaten Merangin Tahun 2016

\begin{tabular}{|c|c|c|c|c|c|c|c|c|}
\hline \multirow{3}{*}{ No } & \multirow{3}{*}{ Puskesmas } & \multicolumn{6}{|c|}{ Informan } & \multirow{3}{*}{ Presentase } \\
\hline & & \multicolumn{2}{|c|}{ Kepala Puskesmas } & \multicolumn{2}{|c|}{ Petugas Kesling } & \multicolumn{2}{|c|}{ Cleaning Service } & \\
\hline & & Ada & Tidak & Ada & Tidak & Ada & Tidak & \\
\hline 1. & Muara Madras & $\checkmark$ & - & $\checkmark$ & - & $\checkmark$ & - & $20 \%$ \\
\hline 2. & Pamenang & - & $\checkmark$ & $\checkmark$ & - & - & $\checkmark$ & 2070 \\
\hline 3. & Meranti & - & $\checkmark$ & - & $\checkmark$ & - & $\checkmark$ & \\
\hline 4. & Muara Delang & - & $\checkmark$ & - & $\checkmark$ & - & $\checkmark$ & \\
\hline 5. & Muara Jernih & - & $\checkmark$ & - & $\checkmark$ & - & $\checkmark$ & \\
\hline 6. & Muara Siau & - & $\checkmark$ & - & $\checkmark$ & - & $\checkmark$ & \\
\hline 7. & Pasar Masurai & - & $\checkmark$ & - & $\checkmark$ & - & $\checkmark$ & $80 \%$ \\
\hline 8. & $\begin{array}{l}\text { Rantau } \\
\text { Panjang }\end{array}$ & - & $\checkmark$ & - & $\checkmark$ & - & $\checkmark$ & \\
\hline 9. & Sungai Bulian & - & $\checkmark$ & - & $\checkmark$ & - & $\checkmark$ & \\
\hline 10. & Sungai Manau & - & $\checkmark$ & - & $\checkmark$ & - & $\checkmark$ & \\
\hline
\end{tabular}

Berdasarkan tabel diatas, hasil wawancara dan telaah dokumen, hanya 20\% Puskesmas Perawatan yang mempunyai SOP pengelolaan sampah medis yaitu Puskesmas Muara Madras dan Puskesmas Pamenang. SOP pengelolaan sampah medis di Puskesmas Muara Madras sudah dijalankan, namun hanya dalam penangganan akhirnya belum menggunakan alat incinerator dikarenakan belum memiliki alat tersebut. Di Puskesmas Pamenang sudah ada SOP pengelolaan sampah medis namun belum dijalankan dan baru dibuat serta belum memberitahukan SOP tersebut kepada kepala puskesmas. Sedangkan $80 \%$ Puskesmas Perawatan di Kabupaten Merangin belum mempunyai SOP tentang pengelolaan sampah medis.

\section{Proses Pengelolaan Sampah Medis}

Proses pengelolaan sampah medis berdasarkan Kepmenkes RI No.1428/Menkes/SK/XII/2006 yaitu mulai dari pemilahan, pengumpulan, pengangkutan, penampungan sementara dan penangganan akhir sampah. Pengolahan sampah medis yang memenuhi standar mengggunakanincinerator dengan suhu diatas $800^{\circ} \mathrm{C}$ sampai $1000^{\circ} \mathrm{C}$ dan pembuangan akhirnya di gali terus ditutup kembali (Sanittarylandfill).

\section{a. Pemilahan}

Pemilahan adalah kegiatan memilih atau memisahkan sampah medis pada tempat sampah di setiap ruangan puskesmas. Pemilahan merupakan tanggung jawab yang dibebankan pada penghasil sampah dan harus dilakukan sedekat mungkin dengan tempat dihasilkanya sampah. Cara yang tepat untuk mengidentifikasi kategori sampah adalah dengan melakukan pemilahan sampah berdasarkan tempat sampah, warna kantong, lebel dan kontainer yang digunakan ${ }^{5}$.

Menurut Kepmenkes RI No. 1428/ MENKES/SK/XII/2006 untuk sampah infeksius atau sampah medis 
menggunakankantong plastik berwarna kuning, benda-benda tajam dan jarum ditampung pada wadah khusus seperti botol, dan sampah domestik menggunakan kantong plastik berwarna hitam, terpisah antara sampah basah dan kering.

Tabel 3. Persentase Sarana Pemilahan Sampah Medis Di Puskesmas Perawatan Kabupaten Merangin Tahun 2016

\begin{tabular}{clccc}
\hline \multirow{2}{*}{ No } & \multirow{2}{*}{ Puskesmas } & \multicolumn{3}{c}{ Sarana Pemilahan } \\
\cline { 3 - 5 } & & Tempat Sampah & Kantong plastik & Pelabelan \\
\hline 1. & Muara Madras & Di Pisah & Pakai Warna Kuning & Ada \\
\hline 2. & Pamenang & Di Pisah & Pakai Warna Hitam & Tidak Ada \\
\hline 3. & Rantau Panjang & Di Pisah & Pakai Warna Hitam & Tidak Ada \\
\hline 4. & Muara Delang & Di Pisah & Tidak Pakai & Ada \\
\hline 5. & Sungai Bulian & Di Pisah & Tidak Pakai & Ada \\
\hline 6. & Meranti & Di Pisah & Tidak Pakai & Tidak Ada \\
\hline 7. & Muara Jernih & Di Pisah & Tidak Pakai & Tidak Ada \\
\hline 8. & Muara Siau & Di Pisah & Tidak Pakai & Tidak Ada \\
\hline 9. & Pasar Masurai & Di Pisah & Tidak Pakai & Tidak Ada \\
\hline 10. & Sungai Manau & Di Pisah & Tidak Pakai & Tidak Ada \\
\hline
\end{tabular}

Berdasarkan tabel diatas hasil wawancara dan observasi menunjukkan bahwa semua puskesmas perawatan $(100 \%)$ melakukan pemisahan sampah medis dan sampah non medis. Dari 10 puskesmas perawatan di Kabupaten Merangin sebanyak 7 puskesmas perawatan (70\%) tidak menggunakan kantong plastik untuk pelapis tempat sampahnya dan 3 puskesmas perawatan $(30 \%)$ menggunakan kantong plastik untuk pelapis tempat sampahnya, dimana 1 puskesmas perawatan (10\%) yang menggunakan kantong plastik sesuai standar yaitu warna kuning dan 2 puskesmas perawatan (20\%) menggunakan kantong plastik warna hitam yang tidak sesuai dengan standar Kepmenkes RI No.1428/ Menkes/ SK/ XII/2006. Pelabelan tempat sampah medis dari 10 puskesmas perawatan sebanyak 3 puskesmas (30\%) melakukan pelabelan untuk tempat sampahnya dan 7 puskesmas (70\%) tidak melakukan pelabelan, dikarenakan tidak adanya dana khusus untuk pengelolaan sampah medis.

\section{b. Pengumpulan}

Pengumpulan adalah proses
penanganan sampah dengan cara
mengumpulkan sampah medis padat dari
masing-masing ruangan puskesmas. Sarana
pengumpulan harus sesuai dengan ketentuan
atau kriteria yaitu tempat sampah medis yang
terbuat dari bahan plastik yang kuat, ringan,
tahan karat, kedap air, permukaan halus pada
bagian dalam, dan memiliki tutup yang mudah
dibuka dan ditutup kembali.

Tabel 4. Persentase Sarana Pengumpulan Sampah Medis Di Puskesmas Perawatan Kabupaten Merangin Tahun 2016

\begin{tabular}{cllc}
\hline No & Puskesmas & \multicolumn{1}{c}{ Sarana Pengumpulan } & Presentase \\
\hline 1. & Meranti & Tempat Sampah Sesuai Kriteria & \\
\hline 2. & Muara Delang & Tempat Sampah Sesuai Kriteria & \multirow{2}{*}{$100 \%$} \\
\hline 3. & Muara Jernih & Tempat Sampah Sesuai Kriteria & \\
\hline 4. & Muara Madras & Tempat Sampah Sesuai Kriteria & \\
\hline 5. & Muara Siau & Tempat Sampah Sesuai Kriteria & \\
\hline 6. & Pasar Masurai & Tempat Sampah Sesuai Kriteria &
\end{tabular}




\begin{tabular}{cll}
\hline 7. & Pamenang & Tempat Sampah Sesuai Kriteria \\
\hline 8. & Rantau Panjang & Tempat Sampah Sesuai Kriteria \\
\hline 9. & Sungai Bulian & Tempat Sampah Sesuai Kriteria \\
\hline 10. & Sungai Manau & Tempat Sampah Sesuai Kriteria \\
\hline
\end{tabular}

Hasil wawancara dan observasi
menunjukkan bahwa semua puskesmas
perawatan (100\%) melaksanakan tahap
pengumpulan sampah medis dengan baik.

\section{c. Pengangkutan}

\begin{tabular}{lcrr}
\multicolumn{2}{c}{ Pengangkutan } & adalah & proses \\
penanganan sampah & dengan & cara \\
menggangkut & sampah medis padat dari \\
masing-masing ruangan puskesmas ke tempat & sementara & (TPS). \\
penampungan & semah & medis dari setiap
\end{tabular}

Hasil wawancara dan observasi dari 10 puskesmas perawatan, 3 puskesmas (30\%) yang melakukan tahap pengangkutan sampah medis menggunakan kantong plastik, sedangkan 7 puskesmas $(70 \%)$ menggunakan tempat sampah dalam tahap pengangkutan sampah medisnya. Jadi dapat disimpulkan bahwa tahap pengangkutan sampah medis di puskesmas perawatan Kabupaten Merangin belum menggunakan alat pengangkut sampah medis sesuai dengan Depkes RI tahun 2002 tentang persyaratan alat pengangkut.

\section{d. Penampungan Sementara}

Penampungan sementara adalah tempat untuk menampung sementara sampah medis padat sebelum dilakukan penanganan akhir. Adapun persyaratan lokasi atau tempat penampungan ruangan menggunakan troli khusus yang tertutup. Adapun persyaratan alat pengangkut sebagai berikut ${ }^{1}$ :

1) Permukaan bagian dalam harus rata dan kedap air.

2) Mudah dibersihkan dan dikeringkan.

3) Sampah mudah diisikan dan dikosongkan.

4) Troli/alat angkut dicuci setelah digunakan.

5) Tidak ada tepi tajam yang dapat merusak kantong atau kontainer selama pemuatan maupun pembongkar muatan. sementara menurut WHO (2005) adalah sebagai berikut $^{11}$ :

1) Area penampungan harus memililki lantai yang kokoh, impermiabel dan drainase. Harus terdapat persediaan air untuk tujuan pembersihan.

2) Mudah dijangkau oleh staf yang bertugas menangani sampah serta kendaraan pengangkut sampah.

3) Persediaan perlengkapan kebersihan, pakaian pelindung dan kantong plastik harus diletakkan dilokasi yang cukup dekat dengan lokasi penampungan sampah.

4) Lokasi penampungan tidak boleh berada didekat lokasi penyimpanan makanan.

5) Harus ada perlindungan dari sinar matahari dan pencahayaan yang baik.

Tabel.6. Persentase Sarana Penampungan Sementara Sampah MedisDi Puskesmas Perawatan Kabupaten Merangin Tahun 2016

\begin{tabular}{|c|c|c|c|}
\hline No & Puskesmas & Sarana Penampungan Sementara & Presentase \\
\hline 1. & Meranti & Tidak Tersedia TPS & \\
\hline 2. & Muara Delang & Tidak Tersedia TPS & \\
\hline 3. & Muara Jernih & Tidak Tersedia TPS & \\
\hline 4. & Muara Madras & Tidak Tersedia TPS & $100 \%$ \\
\hline 5. & Muara Siau & Tidak Tersedia TPS & \\
\hline 6. & Pasar Masurai & Tidak Tersedia TPS & \\
\hline 7. & Pamenang & Tidak Tersedia TPS & \\
\hline
\end{tabular}




\begin{tabular}{clc}
\hline 8. & Rantau Panjang & Tidak Tersedia TPS \\
\hline 9. & Sungai Bulian & Tidak Tersedia TPS \\
\hline 10. & Sungai Manau & Tidak Tersedia TPS \\
\hline
\end{tabular}

Berdasarkan tabel diatas, hasil wawancara dan observasi menunjukkan bahwa semua puskesmas perawatan (100\%) tidak melaksanakan tahap penampungan sementara. Tahap penampungan sementara sampah medis yaitu sampah medis yang berasal dari tempat penghasil sampah di puskesmas, ruang rawat inap, ruang rawat jalan, unit gawat darurat (UGD), poli umum, poli gigi, ruang KIA dan KB serta ruang laboratorium. Ditampung pada tempat sampah di setiap ruangan, lalu diangkut menggunakan troli dan diletakkan ke tempat penampungan sampah sementara. Tempat penampungan semantara harus sesuai kriteria tempat penampungan sementara menurut WHO (2005) sebelum akhirnya dimusnahkan.

\section{e. Penanganan Akhir Sampah Medis}

Penanganan akhir sampah medis adalah tahapan akhir yang paling penting dalam proses pengelolaan sampah medis padat dengan menggunakan alatincenerator serta jika tidak mempunyai alat incinerator harus melakukan perjanjian kerja sama dengan instansi lain, rumah sakit maupun puskesmas lain yang mempunyai alat tersebut dalam pemusnahan sampah medis.

Tabel 7. Persentase Sarana Penangganan Akhir Sampah Medis Di Puskesmas Perawatan Kabupaten Merangin Tahun 2016

\begin{tabular}{|c|c|c|c|}
\hline No & Puskesmas & Sarana Penangganan Akhir & Presentase \\
\hline 1. & Meranti & Dibakar Manual & \multirow{10}{*}{$100 \%$} \\
\hline 2. & Muara Delang & Dibakar Manual & \\
\hline 3. & Muara Jernih & Dibakar Manual & \\
\hline 4. & Muara Madras & Dibakar Manual & \\
\hline 5. & Muara Siau & Dibakar Manual & \\
\hline 6. & Pasar Masurai & Dibakar Manual & \\
\hline 7. & Pamenang & Dibakar Manual & \\
\hline 8. & Rantau Panjang & Dibakar Manual & \\
\hline 9. & Sungai Bulian & Dibakar Manual & \\
\hline 10. & Sungai Manau & Dibakar Manual & \\
\hline
\end{tabular}

Hasil wawancara, observasi dan telaah dokumen menunjukkan bahwa semua puskesmas perawatan $(100 \%)$ melakukan penangganan akhir sampah medis dengan pembakaran manual tidak menggunakan alat incinerator dikarenakan ada sebagian yang alat incinerator rusak dan ada sebagian puskesmas perawatan belum punya alat incinerator. Serta belum semua puskesmas perawatan (100\%) melakukan kerja sama dengan instansi lain maupun rumah sakit dalam hal pemusnahan sampah medis.

Semua puskesmas perawatan di Kabupaten Merangin melakukan pembakaran manual dan setelah itu dilakukan penguburan.
Untuk sampah medis ada yang melakukan pemisahan dalam pembakaran dan ada yang tidak melakukan pemisahan dalam pembakaran. Hanya Puskesmas Rantau Panjang yang sampah medis tidak dibakar, namun sampah medisnya diambil oleh mobil sampah dinas kebersihan setiap 3 hari sekali. Sampah medis tersebut dibawa ke tempat penampungan sampah dan pembuangan akhir sampah. Di tempat pembuangan akhir sampah dinas kebersihan ada atau tidaknya dinas kebersihan melakukan pemusnahan dan sanitarylandfill terhadap sampah medis yang diberikan oleh Puksesmas Rantau Panjang tidak diketahui oleh pihak puskesmas. Sampah medis yang diberikan oleh pihak puskesmas 
Rantau Panjang ke pihak dinas kebersihan tersebut bisa menimbulkan bahaya kesehatan yang lebih besar seperti yang mana sekarang maraknya terjadi pembuatan vaksin palsu, obat palsu, dan jarum suntik yang dibuat mainan untuk anak-anak.

Di puskesmas perawatan Kabupaten Merangin ada 6 puskesmas $(60 \%)$ dari 10 puskesmas perawatan pernah mempunyai incinerator dan keadaan sekarang rusak dan tidak digunakan. Sedangkan yang belum pernah mempunyai incinerator ada 4 puskesmas perawatan (40\%) Namun puskesmas Sungai Bulian mempunyai alat pelebur jarum (distroyersyringe) yang jarang digunakan lagi namun masih bisa digunakan, kendala jarang digunakan dikarenakan listrik yang sering mati lampu.

Pembakaran sampah medis dengan cara manual tidak sesuai dengan Kepmenkes RI No.1428/ Menkes/ SK/ XII/2006 bahwa pemusnahan sampah medis harus menggunakan alat incinerator, hasil dari pemusnahan akan menghasilkan abu pembakaran dari kemudian abu di kubur (metode sanitarylandfill).

\section{Alat Pelindung Diri (APD) Dalam Pengelolaan Sampah Medis}

Menurut Peraturan Menteri Tenaga Kerja dan Transmigrasi Republik Indonesia Nomor Per.08/Men/VII/2010, menyatakan bahwa Alat Pelindung Diri (APD) atau personal protectiveequipment adalah suatu alat yang mempunyai kemampuan untuk melindungi seseorang yang fungsinya mengisolasi sebagian atau seluruh tubuh dari potensi bahaya di tempat kerja. Dalam pengelolaan sampah medis di puskesmas diperlukannya alat pelindung diri (APD) yang berfungsi untuk melindungi diri terhadap faktor bahaya tertusuk jarum, bahaya percikan pembakaran sampah, debu dan bendabenda kecil beterbangan.Petugas penanganan sampah medis harus menggunakan alat pelindung diri (APD) yang terdiri dari topi/helm, masker, pelindung mata, pakaian panjang, apron, pelindung $\mathrm{kaki} / \mathrm{sepatu}$ boot, dan sarung tangan khusus ${ }^{7}$.

Tabel 8. Persentase Penggunaan APD Dalam Pengelolaan Sampah Medis Di Puskesmas Perawatan Kabupaten Merangin Tahun 2016

\begin{tabular}{|c|c|c|c|}
\hline No & Puskesmas & Penggunaan APD & Presentase \\
\hline 1. & Meranti & Tidak menggunakan APD & \multirow{5}{*}{$50 \%$} \\
\hline 2. & Muara Delang & Tidak menggunakan APD & \\
\hline 3. & Pasar Masurai & Tidak menggunakan APD & \\
\hline 4. & Pamenang & Tidak menggunakan APD & \\
\hline 5. & Sungai Manau & Tidak menggunakan APD & \\
\hline 6. & Muara Jernih & Sarung tangan (handscoon), masker & \multirow{5}{*}{$50 \%$} \\
\hline 7. & Muara Madras & Sarung tangan (handscoon), masker & \\
\hline 8. & Muara Siau & Sarung tangan (handscoon), masker & \\
\hline 9. & Rantau Panjang & Sarung tangan (handscoon), masker & \\
\hline 10. & Sungai Bulian & Sarung tangan (handscoon), masker & \\
\hline
\end{tabular}

Hasil wawancara didapatkan bahwa sekitar $50 \%$ petugas cleaning service menggunakan APD dalam mengelola sampah medis sedangkan 50\% petugas cleaning service tidak menggunakan APD. APD yang digunakan belum sesuai dengan standar. Sarung tangan yang dipakai sebagian besar $(50 \%)$ petugas cleaning service belum sesuai, sarung tangan yang dipakai yaitu handscoon. Pada umumnya, puskesmas perawatan Kabupaten Merangin sudah menyediakan alat pelindung diri berupa masker dan sarung tangan. Akan tetapi untuk sepatu boots masih belum ada. Penggunaan juga masih jarang dilakukan karena kurangnya kesadaran dari petugas cleaningservice. Pemeliharaan dan kontrol terhadap alat pelindung diri penting karena alat pelindung diri sensitive terhadap perubahan tertentu, punya masa 
kerja tertentu dan APD dapat menularkan beberapa jenis penyakit ${ }^{8}$

\section{Dampak Langsung Dari Sampah Medis}

Kegiatan puskesmas yang sangat kompleks tidak saja memberikan dampak positif bagi masyarakat sekitarnya, namun dampak negatif berupa cemaran akibat sampah yang dibuang tanpa pengelolaan yang benar. Pengelolaan puskesmas yang tidak baik akan memicu resiko terjadinya kecelakaan kerja dan penularan penyakit dalam bentukinfeksi nosokomial.

Sampah infeksius dapat mengandung berbagai macam mikroorganisme pathogen, dapat memasuki tubuh jika benda itu terkontaminasi resiko ganda inilah (cedera dan penularan penyakit), benda tajam termasuk dalam kelompok sampah yang sangat berbahaya

\section{Tabel 9. Persentase Informan Tentang Dampak Langsung Dari Sampah Medis Di Puskesmas Perawatan Kabupaten Merangin Tahun 2016}

\begin{tabular}{|c|c|c|c|c|c|c|c|c|}
\hline \multirow{3}{*}{ No } & \multirow{3}{*}{ Puskesmas } & \multicolumn{6}{|c|}{ Informan } & \multirow{3}{*}{ Presentase } \\
\hline & & \multicolumn{2}{|c|}{ Kepala Puskesmas } & \multicolumn{2}{|c|}{ Petugas Kesling } & \multicolumn{2}{|c|}{ Cleaning Service } & \\
\hline & & Ada & Tidak & Ada & Tidak & Ada & Tidak & \\
\hline 1. & Meranti & - & $\checkmark$ & $\checkmark$ & - & $\checkmark$ & - & \multirow{3}{*}{$30 \%$} \\
\hline 2. & Muara Jernih & - & $\checkmark$ & - & $\checkmark$ & $\checkmark$ & - & \\
\hline 3. & Rantau Panjang & - & $\checkmark$ & - & $\checkmark$ & $\checkmark$ & - & \\
\hline 4. & Muara Delang & - & $\checkmark$ & - & $\checkmark$ & - & $\checkmark$ & \multirow{7}{*}{$70 \%$} \\
\hline 5. & Muara Madras & - & $\checkmark$ & - & $\checkmark$ & - & $\checkmark$ & \\
\hline 6. & Muara Siau & - & $\checkmark$ & - & $\checkmark$ & - & $\checkmark$ & \\
\hline 7. & Pasar Masurai & - & $\checkmark$ & - & $\checkmark$ & - & $\checkmark$ & \\
\hline 8. & Pamenang & - & $\checkmark$ & - & $\checkmark$ & - & $\checkmark$ & \\
\hline 9. & Sungai Bulian & - & $\checkmark$ & - & $\checkmark$ & - & $\checkmark$ & \\
\hline 10. & Sungai Manau & - & $\checkmark$ & - & $\checkmark$ & - & $\checkmark$ & \\
\hline
\end{tabular}

Berdasarkan tabel diatas, hasil wawancara di Puskesmas Perawatan Kabupaten Merangin didapatkan bahwa $30 \%$ petugas cleaning service pernah tertusuk jarum saat membersihkan sampah medis dan $70 \%$ tidak pernah tertusuk jarum. Kejadian tertusuk jarum pada petugas cleaning service $10 \%$ diketahui oleh petugas kesling dan sekitar 20\% kejadian tidak diketahui. Semua kepala puskesmas (100\%) dan sekitar $90 \%$ petugas kesling tidak pernah mengetahui bahwa petugas cleaning service pernah terkena tusukan jarum saat membersihkan sampah medis. Petugas cleaning service yang pernah tertusuk jarum tidak pernah mengeluh ke pihak puskesmas, hanya dilakukan pengobatan sendiri maka pihak puskesmas tidak memberikan pertanggung jawaban dikarenakan tidak ada keluhan dari petugas cleaning service.

\section{KESIMPULAN}

1. Tingkat pengetahuan petugas medis maupun non medis (kepala puskesmas, petugas kesehatan lingkungan, petugas laboratorium, kepala ruang perawatan, perawat dan petugas cleaning service di puskesmas perawatan Kabupaten Merangin cukup memadai mengenai penjelasan dan contoh dari sampah medis.

2. Pelatihan pengelolaan sampah medis hanya pernah dilakukan oleh satu petugas kesling puskesmas perawatan di Kabupaten Merangin. Sedangkan petugas kesling yang lain dan petugas cleaning service belum pernah mengikuti pelatihan

3. Standar operasional Prosedure (SOP) pengelolaan sampah medis hanya ada di 2 (dua) puskesmas perawatan namun belum dijalankan sesuai Keputusan Menteri Kesehatan No.1428/Menkes/SK/XII/2006.

4. Proses pengelolaan sampah medis di 10 Puskesmas Perawatan memiliki proses yang sama mulai dari pemilahan sampah medis dan sampah non medis, pengumpulan dan pengangkutan sampah ke tempat pembakaran. kemudian dilakukan proses akhir pengelolaan 
sampah medis padat yaitu melalui pembakaran manual.

5. Alat pelindung diri (APD) dalam mengelola sampah medis sudah digunakan sebagian besar petugas cleaning service puskesmas perawatan, sedangkan sebagian petugas cleaning service tidak mengunakan sesuai SOP sehingga kejadian tertusuk jarum pernah dialami oleh sebagian besar petugas cleaning service.

\section{SARAN}

1. Bagi Dinas Kesehatan Kabupaten Merangin

a. Perlu memberikan bimbingan dan pelatihan pengelolaan sampah medis di Puskesmas Perawatan.

b. Perlu melakukan manajemen yang baik meliputi penyediaan SOP, sarana dan prasarana penunjang pengelolaan sampah medis. Misalnya pengadaan alat pelebur jarum (distroyersyringe) dan incinerator. Melakukan pengawasan, pembinaan dan supervisi pengelolaan sampah medis puskesmas perawatan.

c. Membuat MOU dengan rumah sakit Kolonel Abunjani sebagai instansi atau rumah sakit yang mempunyai alat incinerator. Sehingga semua puskesmas perawatan bisa melakukan pemusnahan sampah medis.

d. Perlu memberikan tambahan anggaran untuk pengelolaan sampah medis di puskesmas khususnya puskesmas perawatan.

2. Bagi Puskesmas Perawatan di Kabupaten Merangin

a. Perlu membuat POA untuk pengelolaan sampah medis kemudian diajukan ke Dinas Kesehatan Kabupaten Merangin.

b. Membuat dan merealisasikan SOP pengolahan sampah medis.

c. Perlu pengadaan dan pemeliharaan fasilitasfasilitas dalam pengelolaan sampah medis seperti jumlah tempat sampah, kantong plastik, alat pengangkut sampah berupa gerobak/troli dan Incinerator.

d. Menyediakan alat pelindung diri (APD) untuk cleaning service, yaitu masker pernafasan, sarung tangan bahan karet, dan sepatu boots.

3. Bagi Peneliti Lain
Diharapkan meneruskan penelitian ini dengan jenis, disain, dan cakupan populasi serta sampel yang lebih representatif.

\section{DAFTAR PUSTAKA}

1. Depkes RI. (2002). Pedoman Sanitasi Rumah Sakit Di Indonesia. Jakarta : Departemen Kesehatan RI.

2. Dinkes Kabupaten Merangin. (2015). Profil Dinas Kesehatan Kabupaten Merangin 2015. Merangin: Dinas Kesehatan Kabupaten Merangin.

3. Dyah, P,. (2013). Pengelolaan Limbah Medis Padat Pada Puskesmas Kabupaten Pati, Jurnal Kesmas. Ed. Januari 2013, 9 (1) : 74-84, Semarang. http://journal.unnes.ac.id /nju/index.php/kemas

4. FEMA (1999). DevelopingEffective Standard OperatingProcedures (SOP) forfireand EMS Departments FA-197/ December 1999.

5. Kepmenkes RI. (2006). Nomor 1428/ Menkes/SK/XII/2006 Tentang Pedoman Penyelenggaraan Kesehatan Lingkungan Puskesmas: Jakarta

6. Notoatmodjo, S. (2010). Ilmu Perilaku Kesehatan. Jakarta: Rineka Cipta.

7. Permenakertrans RI. (2010). Peraturan Menteri Tenaga Kerja dan Transmigrasi Republik Indonesia Nomor Per.08/Men/VII/2010 Tentang Alat Pelindung Diri (APD).Berita Negara Republik Indonesia Tahun 2010 Nomor 330. Jakarta.

8. Pruss, dkk. (2005). Pengelolaan aman limbah layanan kesehatan. Jakarta : Penerbit Buku Kedokteran EGC.

9. Pusat Data Dan Informasi, Kemenkes RI. (2015). Jumlah Puskesmas Per Juni 2015 Menurut Provinsi Kabupaten/Kota. Jakarta

10. Undang-undang RI. (2008). Nomor 18 Tahun 2008 Tentang Pengelolaan Sampah. Lembaran Negara Republik Indonesia. 